Original Article

\title{
Three first records of stick insects attacking plants (Inseect: Phasmida) in Tibet
}

\author{
Três primeiros registros de insetos-pau atacando plantas (Inseect: Phasmida) no Tibet
}

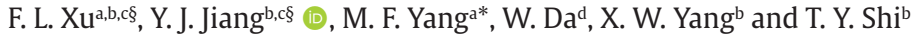 \\ anstitute of Entomology, Guizhou University, Guiyang, Guizhou, P.R. China \\ ${ }^{\mathrm{b} C}$ College of Forestry, Guizhou University, Guiyang, Guizhou, P.R. China \\ 'Research Center for Biodiversity and Natural Conservation, Guizhou University, Guiyang, Guizhou, P.R. China \\ dTibet Plateau Institute of Biology, Lhasa, Xizang Autonomous Prefecture, P.R. China \\ \$The authors contributed equally to this paper.
}

\begin{abstract}
Except for a few stick insects that are economically valuable, most species be considered to be forest pests, so it is extremely important to obtain plant host-use information of more stick insects. In this paper, the plant hosts of three species of stick insects were recorded for the first time. We also discovered these stick insects can feed upon the flowers or leaves of plants. Lopaphus unidentatus (Chen \& He, 1995) (Phasmida: Lonchodidae) attacked Hypericum choisianum Wall. ex N. Robson, 1973 (Hypericaceae), Leurophasma dolichocercum Bi, 1995 (Phasmida: Aschiphasmatidae) attacked Antenoron filiforme (Thunb.) Roberty \& Vautier, 1964 (Polygonaceae) and Megalophasma granulatum Bi, 1995 (Phasmida: Lonchodidae) attacked Debregeasia orientalis C. J. Chen, 1991 (Urticaceae). Finally, we were lucky enough to also obtain photographs of them mating and feeding.
\end{abstract}

Keywords: attacking of flowers, hosts, mating pictures, walking sticks, Tibet.

\begin{abstract}
Resumo
Exceto por alguns insetos-pau que são economicamente valiosos, a maioria das espécies pode ser considerada praga florestal, por isso é extremamente importante obter informações sobre o uso de hospedeiros de plantas de mais insetos-pau. Neste artigo, as plantas hospedeiras de três espécies de bicho-pau foram registradas pela primeira vez. Também descobrimos que esses bichos-pau podem se alimentar de flores ou folhas de plantas. Lopaphus unidentatus (Chen \& He, 1995) (Phasmida: Lonchodidae) atacou a parede de Hypericum choisianum. ex N. Robson, 1973 (Hypericaceae), Leurophasma dolichocercum Bi, 1995 (Phasmida: Aschiphasmatidae) atacou Antenoron filiforme (Thunb.) Roberty \& Vautier, 1964 (Polygonaceae) e Megalophasma granulatum Bi, 1995 (Phasmida: Lonchodidae orientaled) atacou Chen, 1991 (Urticaceae). Finalmente, tivemos a sorte de também obter fotos deles se acasalando e se alimentando.
\end{abstract}

Palavras-chave: ataque de flores, hospedeiros, fotos de acasalamento, bengalas, Tibet.

\section{Introduction}

Except for those few species of stick insects that humans value (Eg. Phyllium celebium, P. siccifolium and $P$. sinensis and so on), most are considered pests (Eg. Rhamphophasma modestum, Ramulus pingliense and Sinophasma largum and so on) that harm plants (Chen, 2008; Xu et al., 2013). Specifically, these insects can cause leaves to become yellow by eating more than half of their surface area, which could lead to a plant's death after many leaves have turned yellow, notable examples of this herbivores are Rhamphophasma modestum Brunner von Wattenwyl, Ramulus pingliense (Chen and He, 1991), R. intersulcatus (Chen and He, 1991), Sinophasma largum (Chen and Chen, 1998), and S. brevipenne Günther, 1940.

They can feed as nymphs or adults to harm trees, such as Quercus spp. (Fagaceae), Castanea spp. (Fagaceae), Betula spp. (Betulaceae), Broussonetia spp. (Moraceae) and so on (Chen, 1993, 2008; Chen and Chen, 1997, 1998; Xu et al. 2013). In China, records of stick insects defoliating trees began in 1985, with published records from Jiangxi Province in 1989, from an total area of ca. 3000 ha (Ding, 1991); from Guangdong Yingde, in total ca. 3500 ha, from 1988 to 1990 (Chen et al., 1994); from Hubei Badong in total ca. 400 ha in 2005 (Tian et al., 2006); from Guizhou Province, in total ca. 30000 ha, from 2009 to 2011 (Xu et al., 2013); Hubei Province, in total ca. 70000 ha, from 2004 to

*e-mail: gdgdly@126.com

Received: November 23, 2020 - Accepted: May 31, 2021

This is an Open Access article distributed under the terms of the Creative Commons Attribution License, which permits unrestricted use, distribution, and reproduction in any medium, provided the original work is properly cited. 
2015 (Zhang et al., 2016), and; from Fujian Province, in total area ca. 1900 ha, from 2010 to 2019 (He et al., 2019).

\section{Materials and Methods}

Photographs were collected from Bome in 22-31-July2020 through Nikon D5300, and insect specimens deposited in the Entomological Specimen Room of College of Forestry from Guizhou University, China. Photos are grouped and annotated with Adobe Photoshop CS6 (version 6.2). Plants' identification was by botanists Mr. An Mingtai.

\section{Records}

\subsection{First record of leaf-eating Lopaphus unidentatus} (Lonchodidae) attacking Hypericum choisianum (Hypericaceae) flowers and leaves

(Figures 1-5)

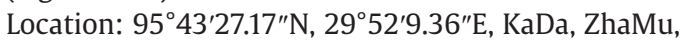
Bome, Tibet

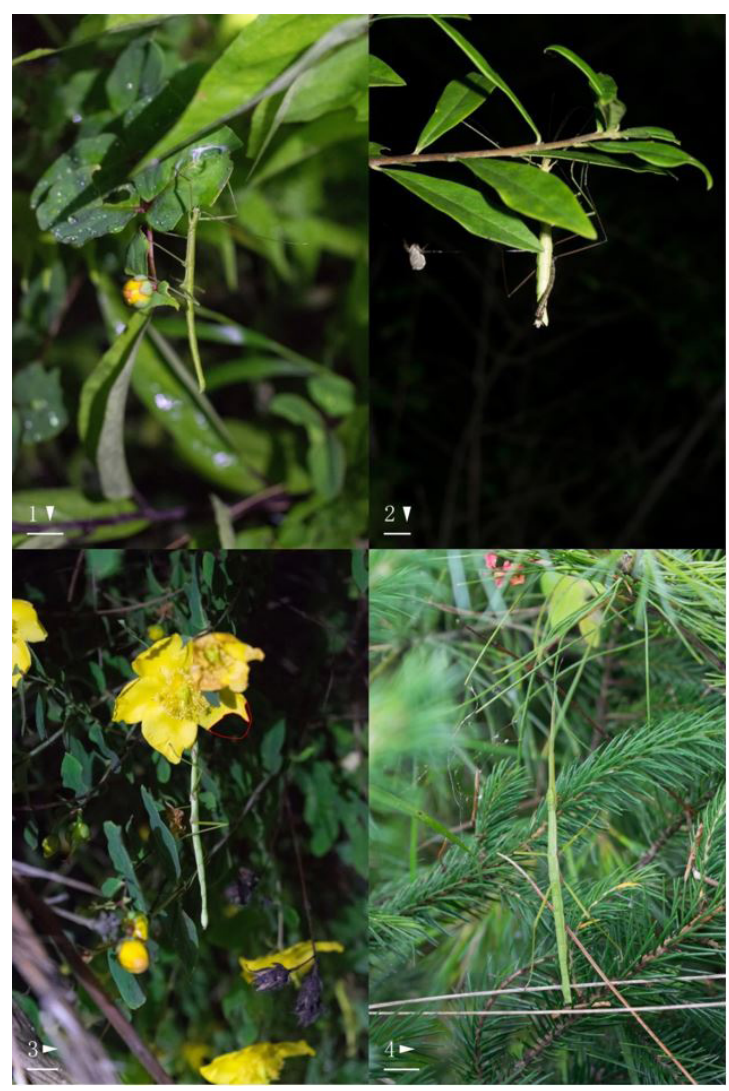

Figures 1-4. Ecological photos of Lopaphus unidentatus. (1) Lo. unidentatus attacking a Hypericum choisianum leaf, 9 ; (2) Mating photo of Lo. unidentatus, $\precsim q$; (3) Lo. unidentatus attacking a Hypericum choisianum flower, + , the red-lined portion is the estimated feeding area; (4) In situ photo of Lo. Unidentatus,. . Scale bars $=10 \mathrm{~mm}$. The arrow points to the ground.
Description: For Lo. unidentatus is Chen \& He made the morphological characteristics records of it for the first time, in 1995 (Chen and He, 1995). This stick insect is distributed in Tibet and Yunnan of China, but there has been no report yet of its host(s) plants. Through a field survey, we found this stick insect species eats $H$. choisianum leaves and flowers, the latter a form of herbivory not documented in previous surveys and reports. Nonetheless, if Lo. unidentatus populations can increase in size to form disastrous outbreaks, this would not good well for the flowers of $H$. choisianum and this plant's reproduction. Adults of Lo. unidentatus were observed to feed from the edges of $H$. Choisianum flowers and leaves, down to the petioles, but they can also eat the bud parts. In addition, we found in our investigation that if $\mathrm{H}$. choisianum and Picea asperata occurred together, then Lo. unidentatus would hang under the needle leaves of $P$. asperata during the daytime, and then proceed to feed on $H$. choisianum during the nighttime. Accordingly, we were able to find more Lo. unidentatus because of this discovery of its hang under the needle leaves of $P$. asperata.

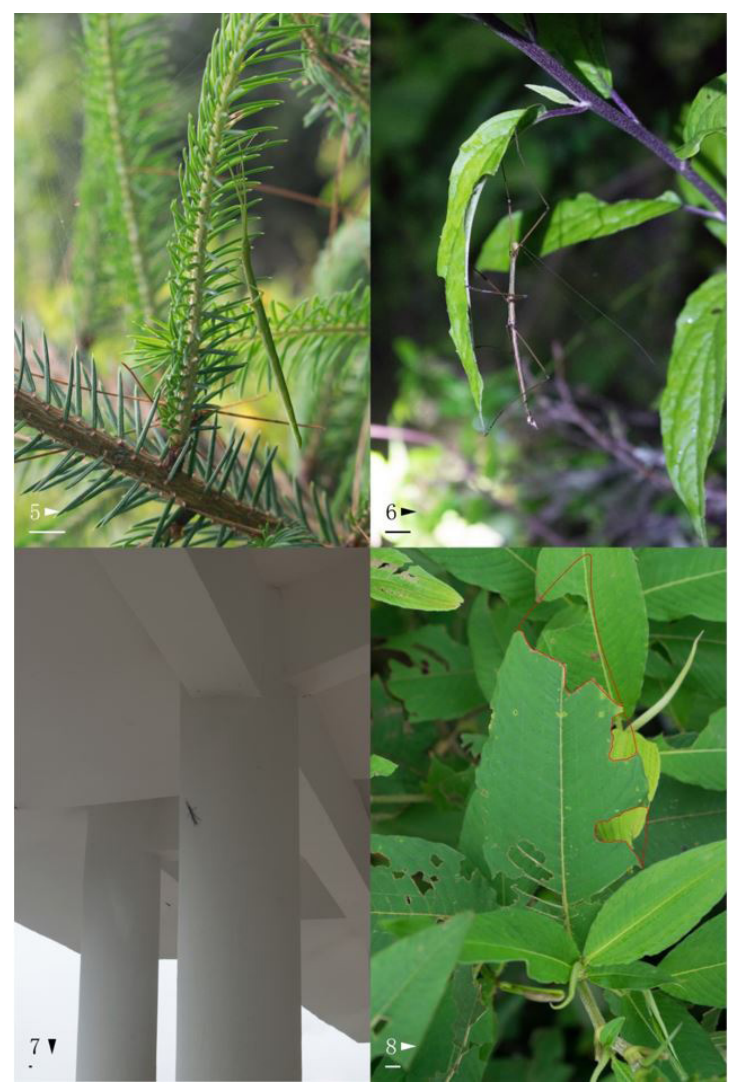

Figures 5-8. Ecological photos of Lopaphus unidentatus and Leurophasma dolichocercum. (5) In situ photo of Lo. unidentatus, †; (6) In situ photo of Lo. unidentatus, 2 ; (7) In situ photo of Le. dolichocercum, o ; (8) Host plant photo of Le. Dolichocercum, the red-lined portion is the estimated feeding area. Scale bars $=10 \mathrm{~mm}$. The arrow points to the ground. 


\subsection{First record of Leurophasma dolichocercum} (Aschiphasmatidae) attacking Antenoron filiforme (Polygonaceae) leaves

(Figures 6-10)

Location: $95^{\circ} 19^{\prime} 14.67^{\prime \prime} \mathrm{N}, 29^{\circ} 18^{\prime} 39.29^{\prime \prime}$ Eand $95^{\circ} 19^{\prime} 2.81^{\prime \prime} \mathrm{N}$, $29^{\circ} 19^{\prime} 0.10^{\prime \prime} \mathrm{E}$, Medog, Bome, Tibet

Description: Le. dolichocercum is a species unique (endemic) to China. It was first recorded by Bi Daoying in 1995 (Bi 1995), but its host plant(s) had not been reported on before. In carrying out the field investigation, we found that Le. dolichocercum takes A. filiforme, two or three Le. dolichocercum adults are often found on a branch of $A$. filiforme. Individuals of Le. dolichocercum will start eating plant tissue from the edge of $A$. filiforme's leaves, or remain along the midrib of mature leaves. In this investigation, we also found that Le. dolichocercum had a very strong jumping ability. When stimulated (poked), or about to be stimulated, they would quickly jump into the air from the front or back of the roosting leaves or stem, falling to the ground and quickly disappearing into the weedy vegetation. Additionally, we find that Le. dolichocercum is capable of securing shelter from rain. When it rains, they will seek out dry places as rain shelter, such as the underside of a

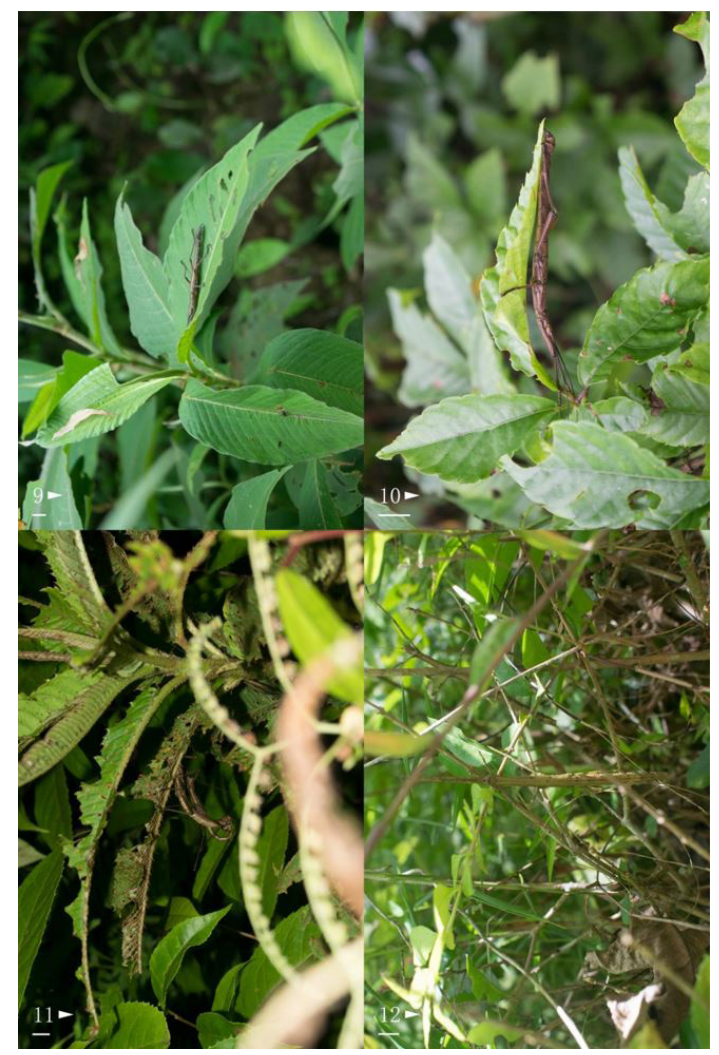

Figures 9-12. Ecological photos of Leurophasma dolichocercum and Megalophasma granulatum. (9-10) In situ photo of Le. dolichocercum, ; ; (11) Mating photo of Le. dolichocercum, $\hat{\jmath}+$; (12) Ecological photo of Megalophasma granulatum, + . Scale bars $=10 \mathrm{~mm}$. The arrow points to the ground. grass blade of golden thread or the bottom of a stalk, or even crawl under a human house to avoid getting wet.

\subsection{First record of Megalophasma granulatum (Lonchodidae) attacking Debregeasia orientalis (Urticaceae) leaves}

(Figures 11-15)

Location: $95^{\circ} 18^{\prime} 1.09^{\prime \prime} \mathrm{N}, 29^{\circ} 19^{\prime} 20.64^{\prime \prime}$ and $95^{\circ} 10^{\prime} 12.97^{\prime \prime} \mathrm{N}$, $29^{\circ} 14^{\prime} 24.58^{\prime \prime}$. Medog, Bome, Tibet.

Description: M. granulatum was described (Bi, 1995). Yet no information about its host appears in the literature. Our investigation revealed that it feeds on $D$. orientalis leaves in our investigation.

\section{Mating of Stick Insects}

(Figures 2, 11, 13, 16)

Description: Their mating position is the male on the back of the female, but the mating position of $L O$. unidentatus and Le. dolichocercum is the male's abdomen is bent from the middle area of the abdomen of the male to the ventral, make their genitals to contact and mate (Figures 2,11). And the mating position of M. granulatum is the male's abdomen is bent from the apex of the abdomen

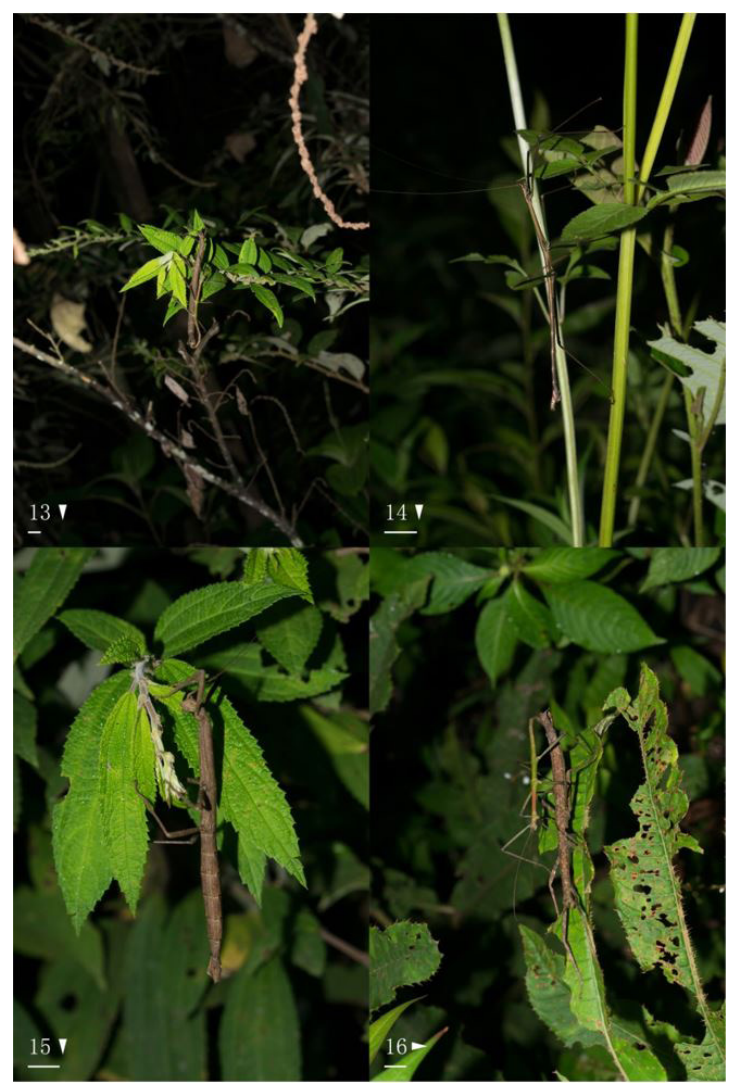

Figures 13-16. Ecological photos of Megalophasma granulatum. (13), (16) Mating photos of M. granulatum, $\hat{\jmath}+$; (14) In situ photo of $M$. granulatum, 3 ; (15) M. granulatum attacking leaves of Debregeasia orientalis. Scale bars $=10 \mathrm{~mm}$. The arrow points to the ground. 
of the male to the ventral, make their genitals to contact and mate (Figures 13,16). These two mating positions are also the way most stick insects mate.

\section{Acknowledgements}

We thank Mr. Yang Zaihua of the Guizhou Forestry Research Institute and Mr. Yu Xiaofei of the Institute of Entomology at Guizhou University for help with the field survey work, and thank Mr. Hou rui of Forertry Coiiege of Guizhou University, for her help in revising the article. We also thank botanists Mr. An Mingtai at the College of Forestry (Guizhou University) for assistance in the plants' identification.

Supported by the Second Tibetan Plateau Scientific Expedition and Research (STEP) program (Grant No. 2019QZKK0501).

\section{References}

BI, D.Y., 1995. Description of three new genera and three new species of Phasmatodea from XiZang, China (Phasmida: Pseudophasmatidae, Heteronemidae). Acta Entomologica Sinica, vol. 38, no. 4, pp. 452-457.

CHEN, S.C., 1993. Description of a new record and two unknown sexes of walking sticks injurious to forest from China (Phasmida: Phasmatidae, Heteronemiidae). Journal of Beijing Forestry University, vol. 15, no. 2, pp. 87-89.

CHEN, S.C., 2008. Phasmatodea of China. Beijing: China Forestry Publishing House, $476 \mathrm{p}$.
CHEN, P.X. and CHEN, S.C., 1997. Identification, biology and control of important stick insects in China. Journal of Beijing Forestry University, vol. 19, no. 4, pp. 70-75.

CHEN, P.X. and CHEN, S.C., 1998. Study on feeding amount and control of Sinophasma largum. Forest Pest Communication, vol. 4, pp. 10-12.

CHEN, S. C. and HE, Y. H., 1991. Three new species of Baculum attacking forest from China (Phasmida: Phasmatidae). Scientia silvae sinicae, vol. 27, No. 3, pp. 229- 233.

CHEN, S.C. and HE, Y.H., 1995. A new species of the genus Paramyronides from China (Phasmida: heteronemiidae).Journal of Beijing Forestry University, vol. 17, no. 3, pp. 73-74.

CHEN, S.L., XU, S.B., LAI, X.H., HU, S.L. and LIN, L.F., 1994. A study on the biological characteristics and control of Micadina yindeensis. Forest Research, vol. 7, no. 2, pp. 187-192.

DING, D.S., 1991. Stick insects have been found to harm forest for the first time in jiangxi province. Jiangxi Forestry Science and Technology, vol. 1, no. 3, pp. 29.

HE, X.Y., SONG, H.T., CAI, S.P., ZHAN, Z.R., SHI, D.Y., ZHEN, Z.F. and XIE, Z., 2019. New forestry pests in Fujian Province in recent years (II) - stick insects. Fujianglinye, vol. 6, pp. 26-29.

TIAN, Z.W., SHU, Y.D., TAN, W.C., WANG, J.R., CHEN, J.H., and WU, Q.F., 2006. Preliminary report on control of stick insect. Protection Forest Science and Technology, Suppl., pp. 78-79.

XU, F.L., YANG, M.F. and SONG, Q.Z., 2013. Occurrence and control of Phasmatodea pests in Guizhou. Guizhou Forestry Science and Technology, vol. 41, no. 2, pp. 60-61.

ZHANG, J.H., CHA, Y.P. and CHEN, J.Y., 2016. Application of Beauveria bassiana mixed with deltamethrin on controlling walking sticks. Hubei Forestry Science and Technology, vol. 45, no. 1, pp. 44-45. 